Fastabiq: Jurnal Studi Islam

ISSN 2723-0228

Vol. 2 No. 1 Bulan Juni Tahun 2021

Halaman 14 - 29

\title{
PERAN ORANG TUA DALAM MENGIMPLEMENTASIKAN PENDIDIKAN KARAKTER PADA MASA PEMBELAJARAN JARAK JAUH
}

\author{
DOI : https://doi.org/10.47281/fas.v2i1.31 \\ Giantomi Muhammad ${ }^{1}$ \\ Universitas Islam Negeri Sunan Gunung Djati Bandung ${ }^{1}$ \\ E-mail: 3200210013@student.uinsgd.ac.id ${ }^{1}$
}

\begin{abstract}
The current pandemic condition means that the learning process is carried out using a remote system. Children learn from home and are guided by their parents, the educational process must not stop even though it is a pandemic. With this, the role of parents at this time is prioritized especially in implementing character education for children during the distance learning period and parents are required to play their current role during the pandemic in implementing character education at home. This research is in the form of qualitative with the literature study method in finding related data and a descriptive-analytic process is carried out. The results of this study suggest three roles of parents in implementing character education, namely the role of parents as educators, motivators for their children, and providing strong role models. This needs to be done with strong intentions and a frequent habituation process.
\end{abstract}

Keywords: Role, Parents, Education, Character

\begin{abstract}
Abstrak
Kondisi pandemi saat ini menjadikan proses pembelajaran dilakukan dengan sistem jarak jauh. Anak belajar dari rumah dan dibimbing oleh orang tuanya, proses pendidikan tidak boleh berhenti meskipun sedang masa pandemi. Dengan hal tersebut peran orang tua pada masa ini sangat diprioritaskan khusnya dalam mengimplementasikan pendidikan karakter kepada anak pada masa pembelajaran jarak jauh dan orang tua dituntut perannya saat ini dikala pandemi dalam pengimplementasian pendidikan karakter di rumah. Penelitian ini berbentuk kualitatif dengan metode studi pustaka dalam menemukan data-data terkait dan dilakukan proses deskriptif analitik. Hasil pada penelitian ini mengemukakan tiga peran orang tua dalam mengimplementasikan pendidikan karakter yakni peran orang tua sebagai pendidik, motivator bagi anaknya dan memberikan keteladan yang kuat. Hal tersebut perlu dilakukan dengan niatan yang kuat dan proses pembiasaan yang sering dilakukan.
\end{abstract}

Kata Kunci: Peran, Orang Tua, Pendidikan, Karakter 


\section{Fastabiq: Jurnal Studi Islam \\ ISSN 2723-0228}

Vol. 2 No. 1 Bulan Juni Tahun 2021

\section{PENDAHULUAN}

Keterlibatan orang tua pada masa pandemi saat ini sangat diperlukan. Orang tua dapat dikatakan menjadi guru sementara dari guru di sekolah. Namun bila ditelaah hakikat sebenarnya orang tua dapat dikategorikan sebagai guru utama bagi anak-anaknya di rumah, karena seorang anak merupakan titipan atau amanah yang diberikan oleh Tuhan kepada pasangan suami dan istri yang selayaknya diberikan arahan, bimbingan, didikan dan pengajaran yang baik oleh orang tuanya. Guru di sekolah hanya sebagai penyempurnaan pengajaran dan pendidikan dari orang tuanya yang mungkin terdapat bidang-bidang tertentu yang tidak dikuasainya sehingga menyerahkannya pada guru di sekolah untuk dibina dengan kesesuain kemampuan ilmu pengetahuan yang dibidangi oleh guru di sekolah.

Banyak sekali keluhan orang tua terhadap pembelajaran dan pendidikan anaknya di rumah selama masa pandemi ini. Orang tua seakan-akan dibuat susah dalam mengajarkan dan mendidik anak-anaknya yang seharusnya dilimpahkan kepada guru di sekolah dan pada masa pandemi ini ketika fungsi guru di sekolah terbatas, tidak bisa melaksanakan pembelajaran secara tatap muka oleh karenanya dilakukanlah pembelajaran daring melalui perangkat ponsel seluler. Otomatis ketika diberlakukannya pembelajaran daring, orang tua memliliki peran sebagai pembina, pendidik dan pengajar bagi anak-anaknya mau tidak mau. ${ }^{1}$ Tetapi masih ada sebagian orang tua yang bersikap keras dalam pendiriannya bahwasannya peran guru-lah yang harus diutamakan meskipun pada masa pandemi saat ini, dengan dalih demikian tidak heran para orang tua terus menggerutu mengenai ketidak sanggupannya dalam mendidik, membina dan mengajar anak-anaknya, maka bisa dilihat ada beberapa anak yang depresi dan stres saat pembelajaran daring diberlakukan saat ini.

Sikap depresi dan stres anak yang mempengaruhi psikisnya kadang dilampiaskan anak dengan hal-hal yang negatif. Pada kasus yang umum ditemukan adalah meningkatnya tingkat kenakalan anak pada masa pandemi baik dari kecanduan permainan daring, pergaulan liar antar sesama remaja, dan kasus-kasus negatif lainnya. Hal tersebut terjadi karena kurangnya pengontrolan terhadap aktivitas anak selama masa pandemi ini oleh kedua orang tuanya. Orang tua seakan-akan telah menyerah dan berputus asa terhadap pendidikan dan pengajaran kepada anaknya, yang dapat diduga kurangnya pemahaman orang tua terhadap mata pelajaran pada bidang tertentu atau faktor lainnya yang mengakibatkan motivasi dalam mendidik dan mengajarkan sesuatu yang posititf terhadap anaknya memudar.

Orang tua seharusnya dapat memahami salah satu hal yang perlu dilakukannya selama masa pandemi saat ini yaitu dengan menguatkan karakter kepribadian anak. Karakter sebagai basis dalam melakukan tindakan yang berujung pada kompleksitas dan aktualitas kepribadian diri sehingga menghasilkan manusia yang beradab dan bermoral ${ }^{2}$. Bila karakter anak telah kokoh maka upaya dalam mencetak genarasi yang unggul dapat tercipta, malah sebaliknya bila karakter seorang anak lemah maka upaya dalam mewujudkan suasana yang harmonis dan humanis tidak terlaksana ${ }^{3}$. Maka dari itu orang tua harus dapat memahami mengenai upaya pelaksanaan pendidikan karakter sebagai 


\section{Fastabiq: Jurnal Studi Islam \\ ISSN 2723-0228}

Vol. 2 No. 1 Bulan Juni Tahun 2021

sarana dalam menanamkan nilai-nilai karakter pada kepribadian anak sehingga karakter yang kokoh dapat terpatri dalam kepribadian anak yang mencipatakan genarasi yang beradab dan bermoral dapat terbentuk dengan baik.

Pendidikan karakter merupakan alternatif yang perlu dilakukan oleh orang tua dirumah selama masa pendemi ini. Ketika orang tua tidak menguasai salah satu bidang tertentu dalam mata pelajaran anak-anaknnya, namun dirasa orang tua mampu memberikan pendidikan karakter yang baik pada anak-anaknya, Pendidikan karakter merupakan upaya penerapan pembiasaan yang baik yang dilakukan dengan pembiasaan yang rutin dan terkonsentrasi. Pelasanaan pendidikan karakter tidak melulu dilakukan di sekolah oleh guru, dirumah pun dapat terwujud oleh orang tua, apalagi menimbang kedekatan orang tua dan anak yang telah terjalin hubungan darah diantara keduanya yang menjadikan pendidikan karakter dapat berfungsi dengan baik dan tujuan yang diharapkannya dapat tercapai.

Terdapat penelitian Kurniati $\mathrm{dkk}^{4}$ mengenai peran orang tua dalam mengawasi anak pada masa pandemi, dimana peran orang tua sebagai pendidik, pembimbing, penjaga, pembina dan pengawas bagi anak-anaknya, secara keseluruhan peran tersebut sebagai pelaksanaan keseharian, baik dalam kegiatan pendidikan, finasial, maupun kegiatan lainnya yang perlu dilakukan orang tua terhadap anaknya sehingga memiliki nilai edukasi tersendiri bagi anak-anaknya. Dalam penelitian Lilawati ${ }^{5}$ peran orang tua dalam mendukung pembelajaran anak dari rumah selayaknya dilakukan dengan pendampingan yang terpadu dan memberikan motivasi kuat pada anaknya dan juga upaya orang tua dalam melengkapi fasilitas pembelajaran yang sesuai saat proses pembelajaran dilakukan. Disamping peran orang tua saat masa pandemi, penelitian dari Dewi \& Khotimah ${ }^{6}$ menjadikan pola asuh orang tua terhadap anaknya di rumah harus dilakukan dengan baik dalam artian bahwasannya orang tua selain harus mengetahui perannya selama ini pada saat proses pembelajaran jarak jauh juga dituntut dapat menerapkan pola asuh yang baik kepada anak.

Dari ketiga penelitian tersebut semuanya membahas mengenai peran orang tua yang harus dilakukan terhadap anaknya selama masa pandemi ini. Penekanan akan upaya dalam menjalankan perannya, orang tua pun harus mengetahui pola dari penerapannya yang perlu diberlakukan terhadap pendampingan pembelajaran selama ini pada anaknya di rumah. Yakni secara khusus memberikan pemahaman dan pengertian langkah-langkah yang harus dilakukan orang tua dalam pendamping anaknya pada masa pandemi ini dalam ruang lingkup terbatas dan tidak bertatap muka secara langsung dengan guru di sekolah.

Pada penelitian yang akan dilakukan oleh peneliti pada artikel ini selain memberikan pemahaman pada orang tua sebagai pendamping anak di rumah saat masa pembelajaran jarak jauh, artikel penelitian ini memberikan suatu pemahaman akan pentingnya mengimplementasikan pendidikan karakter yang harus dilakukan oleh orang tua terhadap anaknya. Pendidikan karakter harus tetap berjalan meskipun dalam ruang lingkup terbatas dari rumah antara anak dan orang tua. Biasanya pendidikan karakter selalu diterapkan di sekolah oleh guru terhadap siswa. Namun pada 


\section{Fastabiq: Jurnal Studi Islam \\ ISSN 2723-0228}

Vol. 2 No. 1 Bulan Juni Tahun 2021

masa pandemi saat ini sulit rasanya bila hanya guru saja yang perlu menerapkan pendidikan karakter terhadap siswa dari rumah. Pendidikan karakter efektif dilakukan bila antara subjek dan objek dapat berpapasan secara langsung dan penerapan yang dilakukan secara faktual dan komprehensif dalam kenyataan yang utuh. Pada masa pandemi saat ini, hanya orang tua yang memiliki kriteria demikian sedangkan guru di sekolah tidak dapat secara maksimal dalam menerapkannya. Peran orang tua dalam mengimplementasikan pendidikan karakter pada pembelajaran jarak jauh dirasa penting pada saat ini dan orang tuapun harus dapat mengetahuinya.

Rumusan masalah dalam penelitian ini berupaya memberikan masukan untuk menjalankan peran orang tua dalam mengimplementasikan pendidikan karakter dari rumah pada proses pembelajaran jarak jauh yang dilakukan saat ini, hal tersebut yang tidak dapat dilakukan secara maksimal oleh guru di sekolah dikeranakan pembatasan interaksi yang harus dilakukan dan pembelajaran dilakukan secara daring. Sedangkan tujuan dalam penelitian ini mengupayakan para orang tua agar memahami perannya selama masa pembelajaran jarak jauh bahwasannya pengimplementasian pendidikan karakter dapat dilakukan di rumah oleh orang tua terhadap anaknya. Meskipun sekolah pada masa ini tidak terlalu berperan banyak dalam pengimplementasian pendidikan karakter, maka orang tua dapat menjadi penyempurna dalam pengimplementasian pendidikan karakter terhadap anaknya.

\section{METODE PENELITIAN}

Metode yang digunakan penulis dalam penulisan artikel ini dengan menggunakan metode studi riset kepustakaan (Library Research) dalam menemukan data yang relevan sesuai dengan pokok pembahasan penelitian ini. Setelah ditemukan data yang diinginkan maka dilakukan analisis bacaan yang bersumber dari buku, jurnal dan bahan bacaan yang sesuai dengan mengunakan metode analisis isi (Contect Analysis). Dilanjutkan untuk keseluruhan data dalam memaksimalkan penelitian dilakukan proses lanjutan pengumpulan data dengan metode deskriptif analitik dari berbagai sumber bacaan.

Pada proses sitasi pengutipan referensi hasil bacaan, penulis menggunakan aplikasi Mendeley untuk menyesuaikan referensi bacaan dengan tujuan penelitian ini dilakukan. Tahapan akhir dalam pengelolaan data hasil penelitian, penulis melakukan proses pengolahan dan penyusunan data terkait. Peneliti juga melakukan proses analisis deskriptif dan interpretasi data dari berbagai sumber bacaan sebagai cara yang penulis tuangkan dalam menyusun pendapat-pendapat yang sesuai dengan pembahasan pada artikel ini.

\section{HASIL DAN PEMBAHASAN}

\section{Pengertian Pendidikan Karakter dan Pembelajaran Jarak Jauh}

Pendidikan merupakan usaha sadar dan terencana untuk mewujudkan suasana belajar dan proses pembelajaran secara aktif dalam upaya mengembangkan potensi diri dalam mewujudkan sikap spritual, pengendalian diri, membentuk kepribadian, kecerdasan, ahlak mulia, serta PERAN ORANG TUA DALAM MENGIMPLEMENTASIKAN PENDIDIKAN KARAKTER PADA MASA PEMBELAJARAN JARAK JAUH 


\section{Fastabiq: Jurnal Studi Islam \\ ISSN 2723-0228}

Vol. 2 No. 1 Bulan Juni Tahun 2021

keterampilan yang diperlukan oleh diri sendiri dan masyarakat sekitar ${ }^{7}$. Dalam hal ini pendidikan bertujuan untuk memanusiakan manusia sesuai fitrahnya dengan kapasitas sebagai mahluk hidup yang berakal yang mampu memberikan kedamaian dan pengolahan sikap dalam menunjang stabilitas ekosistem dunia.

Karakter dapat diartikan sebagai nilai-nilai, sikap dan perilaku yang dapat diterima oleh masyarakat luas. Karakter tersebut dapat berupa sikap etis, demokratis, hormat, bertanggung jawab, dapat dipercaya, adil dan peduli. Sumber dari karakter sendiri antara lain dari nilai-nilai kemasyarakatan, ideologi negara, kewarganegaraan, nilai-nilai budaya bangsa, agama, dan etnik yang diterima oleh masyarakat Indonesia secara luas dan tidak menimbulkan konflik dan pertentangan ${ }^{8}$. Karakter tidak lain merupakan suatu bentukan dari nilai kebiasaan yang timbul pada lingkungan sekitar. Proses pembiasaan yang terus diulang-ulang secara konsisten membentuk karakter seseorang pada lingkup wilayah yang terkondisikan memliki aktivitas yang mendukung dan dapat diterima serta dipahami oleh masyarakat sekitar.

Melihat keterpaduan antara pendidikan dan karakter memberikan pengertian bahwasannya pendidikan karakter merupakan upaya dalam membuat suatu pembelajaran yang mengedepankan nilai, perilaku dan sikap yang berlaku secara umum pada masyarakat luas umumnya. Pendidikan karakter memberikan perencanaan yang terstruktur dengan baik sebagai wadah dalam membentuk etika dan moral bermasyarakat sehingga membentuk nilai peradaban yang humanis dibarengi dengan nilai-nilai universal kemanusiaan yang memiliki peranan dalam melestarikan kehidupan yang penuh kedamaian.

Pendidikan karakter menurut Lickona $^{9}$ merupakan usaha sengaja dalam mewujudkan kebajikan antar sesama manusia sehingga manusia dapat membentuk kualitas kemanusiaan yang baik secara objektif. Bukan hanya perorangan dalam memunculkan kebaikannya tersebut melainkan secara bersamaan antara satu orang dengan orang yang lain, hingga menyebar dalan satu kelompok kemasyarakatan. Pada pengertian yang lain Tafsir...mengistilahkan pendidikan karakter dengan pendidikan akhlak yang maknanya hampir sama yakni membentuk kepribadian yang baik didasari dengan kesadaran penuh bahwasannya kebaikan yang terbentuk dalam diri memberikan dampak positif bagi lingkungan sekitarnya. Sedangkan Marzuki ${ }^{10}$ mengemukakan bahwasannya pendidikan karakter merupakan aspek yang dilakukan dengan kesadaran untuk menumbuhkan karakter mulia.

Dari definisi tersebut dapat diartikan bahwasannya pendidikan karakter perlu dilakukan secara sadar dan memiliki tujuan yang ingin dicapai serta mekanisme penerapannya terstruktur dengan baik serta pengawasan yang dilakukan benar-benar terkontrol dikarenakan tujuan pendidikan karakter membentuk sifat yang mulia pada diri seseorang oleh karenanya tidak asal melakukan penerapan pendidikan karakter tanpa pemahaman dan kesesuaian khusus, dan hal tersebut perlu dilakukan pembiasaan yang aktif atau konsisten.

Pembelajaran jarak jauh (distance learning) merupakan pembelajaran yang dilakukan dengan media elektronik sehingga terjadi interaksi antara guru beserta peserta didik namun tidak PERAN ORANG TUA DALAM MENGIMPLEMENTASIKAN PENDIDIKAN KARAKTER PADA MASA PEMBELAJARAN JARAK JAUH Giantomi Muhammad 


\section{Fastabiq: Jurnal Studi Islam \\ ISSN 2723-0228}

Vol. 2 No. 1 Bulan Juni Tahun 2021

bertatap muka secara langsung. Pembelajaran jarak jauh juga biasa disebut dengan pendidikan jarak jauh (distance education) dikarenakan jarak antara guru dan peserta didik berjauhan dan diperlukan alat komunikasi khusus berbentuk media elektronik daring. Arahan-arahan pembelajaran yang biasa dilakukan dalam pembelajaran jarak jauh oleh guru berupa penugasan atau hal sejenis yang dapat mengembangkan wawasan pengetahuan peserta didik $^{11}$.

Awal mula pelaksanaan pembelajaran jarak jauh dilakukan dengan kursus tertulis, seiring dengan perkembangan waktu dikembangkan dalam pendidikan tinggi formal berbentuk universitas terbuka (Open University) salah satunya di University of Wisconsin Amerika Serikat yang menyelenggaeakan pembelajaran jarak jauh. Pada saat itu pembelajaran jarak jauh dilakukan sebagai cara untuk memfasilitasi para pekerja yang ingin melanjutkan perkuliahannya tetapi terhalang oleh waktu kerja yang memungkinkan tidak dapat hadir di lokasi perkuliahan, oleh karena itu pihak universitas memfasilitasinya dengan pembelajaran jarak jauh menggunakan media elektronik laptop atau handphone sehingga proses perkuliahan dapat berjalan meskipun mahasiswa dan dosennya tidak pada satu lokasi khusus ${ }^{12}$.

Pelaksanaan pembelajaran jarak jauh menurut $\mathrm{Nata}^{13}$ merupakan tantangan dan peluang dalam pendidikan pada masa sekarang ini. Menjadi tantangan bagi pengelola lembaga pendidikan dan guru untuk dapat memacu adrenalin dalam mengembangkan kemampuan teknologi dalam pelaksanaan pengajaran dan pembelajaran, begitupun bagi peserta didik dituntut untuk mengembangkan Ilmu Pengetahuan dan Teknologi (IPTEK). Begitupun peluang dalam pembelajaran jarak jauh yaitu memudahkan seseorang dalam menerima pembelajaran dan pendidikan dimanapun dan kapanpun tanpa terkendala akses ke lokasi, hanya saja dalam pembelajaran jarak jauh perlu memfasilitasi diri dengan perangkat teknologi yang memadai dalam pelaksanaan pembelajaran jarak jauh.

\section{Peran Orang Tua Dalam Mengimplementasikan Pendidikan Karakter}

Orang tua sebagai pembimbing, pengayom dan pelindung bagi anak-anaknya memiliki peran yang besar dalam membesarkan anak-anaknya. Perannya tersebut bukan hanya menafkahi dan melindungi anak-anaknya sebatas pemenuhan sandang, papan dan pangan semata namun dalam memenuhi wawasan dan pengetahuan bagi anak-anaknya terutama memberikan pendidikan terbaik sebagai bekal psikis dan moril kepribadian anak-anaknya pada masa dewasa nanti. Selain memberikan fasilitas pendidikan yang baik seperti menempatkannya pada sekolah terbaik dibalik itu orang tua memiliki peran pendidikan yang harus dilakukan dalam membimbing anak di rumah. Sentuhan pendidikan bagi anak tidak sebatas hanya guru di sekolah saja, orang tua di rumah harus menguatkan pendidikan yang diterima anak di sekolah, sehingga keterpenuhan pendidikan bagi anak tercukupi dan memberikan dampak yang baik bagi anak pada masa dewasa nanti.

Orang tua merupakan guru terbaik bagi anak-anaknya dikarenakan kedekatan yang terjalin secara panjang, dibalik itu keterikatan jalinan orang tua dan anak yang saling memahami dan 


\section{Fastabiq: Jurnal Studi Islam \\ ISSN 2723-0228}

Vol. 2 No. 1 Bulan Juni Tahun 2021

mengerti. Dalam menemukan kemampuan anak sebenarnya orang tua mampu melakukan hal tersebut dengan tindakan discovering ability yaitu menjelajah kemampuan anak sehingga anak terbangun konsep diri positif dalam kepribadian anak ${ }^{14}$.

Peran orang tua sangat dibutuhkan besar sebagai upaya dalam mengembangkan sikap afektif, kognitif dan psikomotorik anaknya dikarenakan dengan memberikan pendidikan yang berkualitas sehingga dapat mensinergikan peran sekolah, guru dan orang tua menjadi suatu kestabilan dalam memenuhi nilai-nilai karakter sebagai pengembangan etika dan moral. Diantara peranya adalah sebagai beriku:

\section{1) Orang Tua Sebagai Pendidik di Rumah}

Pendidik adalah mereka yang memiliki tanggung jawab dan mempengaruhi jiwa serta rohani yakni dari segi pertumbuhan jasmaniyah, pengetahuan, keterampilan, dan aspek rohaniyah ${ }^{15}$. Pendidik merupakan pembimbing pada proses pendidikan yang terarah dan terprogram dengan baik untuk berupaya mencapai pada tujuan dari dilaksanakannya proses pendidikan. Pendidikan yang baik perlu dilakukan pengarahan dan pembimbingan dari orang yang mampu bertanggung jawab dan dapat mempengaruhi kepribadian seseorang. Pendidik harus dapat memberikan pengarahan mengenai apa yang baik dan juga yang buruk, mana yang harus dilakukan dan juga mana yang harus ditinggalkan.

Tugas sebagai pendidik tidak hanya dibebankan kepada seseorang yang berprofesi sebagai pendidik saja, akan tetapi adalah semua orang tua, anggota masyarakat dalam lingkungan dimana individu itu berada serta lingkungan kemasyarakatan keagamaan. Peranan orang tua dalam mendidik agar anak dapat hidup dengan baik, bahkan lebih dari itu agar anak dapat tumbuh dewasa ${ }^{16}$. Peran orang tua sebagai pendidik utama bagi anak-anaknya dan hal tersebut tidak dapat disanggah. Anak sebagai buah hati yang dilahirkan dan dibesarkan oleh kedua orang tua selayaknya dapat dididik dengan baik karena proses pendidikan merupakan proses dalam menanamkan nilai-nilai yang baik bagi kepribdian anak agar menjadi pribadi yang tangguh, mandiri, beriman dan bertanggung jawab.

Orang tua merupakan pendidik bagi anaknya dirumah, sikap orang tua yang dilakukan di rumah menjadi contoh bagi anaknya. Layaknya seorang pendidik, orang tua harus mampu menekankan nilai-nilai karakter yang baik dan juga melakukan pengawasan terhadap anaknya. Apa yang dilakukan oleh orang tua dalam mendidik anaknya kiranya bernilai positif bagi tumbuh kembang anak. Diandha ${ }^{17}$ mengungkapkan dalam penelitiannya bahwasannya keterlibatan orang tua dalam pendidikan anak dapat diwujudkan dalam berbagai bentuk aktifitas yang dilakukan oleh orang tua melalui kerjasama dengan guru baik di rumah ataupun di sekolah, dengan maksud dapat memaksimalkan perkembangan dan pendidikan dari anak.

Proses kerjama antara orang tua dan guru sebagi upaya dalam menjalin komunikasi dan proses pemantauan antara kedua belah pihak, dengan hal tersebut diharapkan dapat membentuk karakter kepribadian anak. Terutama dalam masa Pembelajaran Jarak Jauh (PJJ) dimana peran guru 


\section{Fastabiq: Jurnal Studi Islam \\ ISSN 2723-0228}

Vol. 2 No. 1 Bulan Juni Tahun 2021

sebagai pendidik di sekolah tidak dapat terealisasikan dengan baik dikarenakan keterbatasan jarak, oleh karenanya orang tua dapat sebagai pengganti dan juga pelaksana pendidik untuk menerapkan proses pendidikan dari rumah. Iftitah dan Anawaty ${ }^{18}$ menyatakan bahwa proses pembimbingan orang tua terhadap anaknya dalam pembelajaran jarak jauh dapat menghilangkan rasa sendiri dan membangun kedekatan antara orang tua dan anaknya. Orang tua sebagai pendidik di rumah harus dapat meluangkan waktu dan memberikan fasilitas pembelajaran meliputi lingkungan belajar dan sumber belajar yang menyenangkan sehingga dapat meminimalisir kejenuhan saat proses pembelajaran jarak jauh.

Peran orang tua sebagai pendidik selama pembelajaran jarak jauh di rumah selayaknya mampu memberikan pengarahan yang maksimal dalam terlaksanakannya pendidikan karakter bagi anaknya. Proses pengimplementasian pendidikan karakter pada pembelajaran jarak jauh dapat dilakukan apabila orang tua menyadari posisinya sebagai seorang pendidik yang dapat menanamkan nilai-nilai karakter pada kepribadian anaknya. Dengan proses pengarahan dari guru di sekolah melalui sistem daring seharusnya menjadi kemudahan bagi orang tua dirumah dalam menerapkan pendidikan karakter selama masa pembelajaran jarak jauh. Kerjasama antara sekolah dan orang tua dalam masa pembelajaran jarak jauh harus lebih diperhatikan untuk menghindari hal yang dapat mengakibatkan kekosongan pada upaya pengimplementasian pendidikan karakter pada anak selama di rumah.

\section{2) Memberikan Motivasi Belajar}

Motivasi merupakan serangkaian usaha untuk menyediakan kondisi-kondisi tertentu, sehingga seseorang mau dan ingin melakukan sesuatu dan apabila ada sesuatu yang dirasa tidak disukai maka akan membuangnya rasa ketidak sukaan tersebut, motivasi dapat dirangsang oleh faktor luar, tetapi motivasi itu tumbuh dalam kepribadian orang dan lingkungan yang menjadi faktor luar sebagai tempat munculnya motivasi dalam kepribadian seseorang ${ }^{19}$. Motivasi memberikan efek positif pada kepribadian seseorang sehingga menimbulkan rasa suka dan mau dalam melaksanakan suatu hal. Proses pemberian motivasi dilakukan dengan cara menarik hati dan minat seseorang, memberikan respon-respon positif dan wawasan yang inspiratif sehingga motivasi dapat timbul dengan baik pada kepribadian seseorang.

Dalam proses pembelajaran, peran motivasi sangat dibutuhkan sebagai perangsang semangat dalam melakukan pembelajaran. Menurut $\mathrm{Emda}^{20}$ motivasi merupakan salah satu faktor seseorang dalam menumbuhkan minat belajarnya. Motivasi belajar dapat dikatagorikan menjadi dua yaitu motivasi instrintik adalah motivasi yang timbul dalam diri seseorang sehingga dapat mendorongnya dalam tindakan belajar, sedangkan motivasi ekstristik adalah motivasi yang timbul diluar diri seseorang yang mendorongnya dalam kegiatan belajar.

Keterlibatan orang tua dalam proses pembelajaran anak dengan dorongan-dorongan yang ditujukan pada anak sehingga melakukan hal dengan rasa suka merupakan motivasi instrinsik yaitu motivasi yang timbul dari dalam kepribadian anak ${ }^{21}$. Orang tua merupakan motivator bagi anaknya, 


\section{Fastabiq: Jurnal Studi Islam \\ ISSN 2723-0228}

Vol. 2 No. 1 Bulan Juni Tahun 2021

proses cinta dan kasih sayang antara anak dan orang tuanya menimbulkan suatu kesan kedekatan dan implikasinya terhadap proses memotivasi bila dilakukan dengan cinta dan kasih sayang akan menghasilkan suatu hasil yang baik dan diharapkan dapat perpengaruh kuat pada keperibadian anak

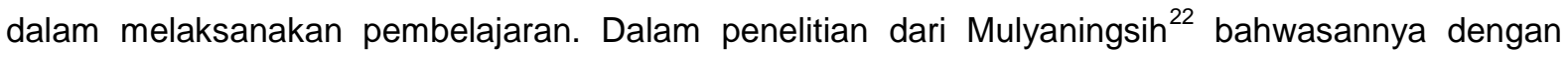
dilakukannya upaya interaksi sosial dalam keluarga secara aktif dan upaya dalam memotivasi belajar anak dapat meningkatkan prestasi anak khususnya dalam pembelajaran. Dengan kata lain, semakin intensif interaksi sosial anak dalam keluarga, motivasi belajarnya semakin meningkat. Begitu juga dengan kemandirian belajarnya yang pada gilirannya meningkatnya prestasi belajar ${ }^{23}$.

Orang tua dapat memberikan motivasi belajar pada pembelajaran jarak jauh berupa kata-kata dan tindakan yang positif pada kepribadian anak. Pemberian motivasi pada pelaksanaan pembelajaran jarak jauh di masa pandemi covid-19 saat ini sangat dibutuhkan baik diberikan oleh orang tua dan guru, dengan diberikannya motivasi tersebut diharapkan dapat memberikan efek semangat kepada anak untuk tetap fokus, berdisiplin dan konsisten dalam melaksanakan pembelajaran jarak jauh. Motivasi berupa kata-kata dapat juga dilakukan dengan memberikan pesanpesan positif yang menggairahkan minat anak, dengan kata lain memberikan motivasi instristik yang bersifat mempengaruhi kepriadian anak dari dalam. Upaya memberikan motivasi dengan kata-kata agar dapat diterima oleh anak secara logis dan rasional untuk mempengaruhi perasaan dan daya pikir anak. Kalimat-kalimat positif yang bersifat menyemangati anak misalnya "Ayo semangat belajarnya, agar pintar dan cita-cita kamu mudah tercapai !" atau kalimat-kalimat lainnya yang dapat dipahami oleh anak. Motivasi berupa tindakan dapat dilakukan dengan memberikan fasiltas yang mendukung anak dalam melaksanakan pembelajaran jarak jauh. Motivasi berupa tindakan dapat dikategorikan kedalam motivasi ekstristik yaitu motivasi yang timbul dari luar kepribadian anak disebabkan faktor-faktor pendukung yang bersifat materi. Orang tua dapat melakukan hal tersebut dengan memberikan ruang yang nyaman, sumber buku pelajaran yang menyenangkan anak, memberikan konsumsi yang disukai anak atau hal-hal lain yang dapat menunjang anak dalam melaksanakan pembelajaran jarak jauh.

Menurut penlitian dari Cahyani $\mathrm{dkk}^{24}$ motivasi belajar siswa pada masa pandemi saat ini sangat menurun dalam pembelajaran daring jarak jauh. Motivasi belajar yang menurun karena faktor ruang lingkup manusia yang dibatasi dalam upaya pencegahan covid-19 terutama dalam sektor pendidikan di persekolahan, suatu aktivitas yang biasanya dilaksanakan secara normal tiba-tiba berubah derastis dan dampak dari hal ini menjadi suatu kewajaran yaitu menimbulkan kejenuhan dan keresahan khusunya dalam pembelajaran jarak jauh. Kurnianto dan Rahmawati ${ }^{25}$ berpendapat bahwasannya pola asuh orang tua selama pembelajaran jarak jauh dirumah memiliki hubungan positif terhadap motivasi belajar anak selama di rumah, pola bimbingan orang tua terhadap anaknya dapat meningkatkan motivasi belajarnya selama pembelajaran jarak jauh. Orang tua telah lebih lama tahu akan sifat kepribadian anaknya, maka dalam proses pembelajaran jarak jauh peran orang tua selain sebagai pendidik juga sebagai motivator bagi anaknya. Proses pengimplementasian pendidikan karakter pada pembelajaran jarak jauh harus dibarengi dengan motivasi yang sering 


\section{Fastabiq: Jurnal Studi Islam \\ ISSN 2723-0228}

Vol. 2 No. 1 Bulan Juni Tahun 2021

dilakukan oleh orang tua agar menimbulkan motivasi belajar anak selama masa pembelajaran jarak jauh di rumah.

\section{3) Keteladanan dari Orang Tua}

Model keteladanan dalam proses pendidikan merupakan bagian dari sejumlah metode yang efektif dalam mempersiapkan dan membentuk anak secara moral, sosial dan spiritual, dikarenakan seorang pendidik merupakan contoh ideal dalam pandangan anak, segala tingkah laku, perkataan dan tindakannya akan ditiru oleh anak dalam kesehariannya ${ }^{26}$. Ki Hajar Dewantoro telah memberikan kata-kata petuah mengenai proses keteladanan dari seorang pendidik "ing ngarso sung tulodo ing madyo mangun karso tut wuri handayani" yang artinya di depan memberikan teladan, di tengah membangun kemauan, di belakang memberikan dorongan. Menurut Raharjo ${ }^{27}$ Melalui keluargalah pembentukan karakter dibentuk dan terpelihara, anak-anak otomatis mencontoh dan meneladani perilaku dari para orang tuanya. Jika orang tua memberikan contoh yang baik secara konsisten baik ucapan, perilaku dan tindakan dalam keseharian, maka anak akan mengikuti dan meneladani apa yang dilakukan orang tuanya dengan rasa hormat. Tetapi sebaliknya, jika orang tua memerintahkan anaknya untuk bertindak disiplin dan berbuat baik, sementara ia bertindak sebaliknya, maka anak mungkin menurut jika di hadapan orang tuanya saja, tetapi diluar tersebut tanpa sepengetahuan orang tuanya anak tersebut bertindak sebaliknya.

Orang tua merupakan model hidup (live model) bagi anak-anaknya, sehingga apa yang dilakukan orang tua akan selalu dipraktikan oleh anak. Dapat dikatakan orang tua merupakan idola pertama dari seorang anak, karena ruang lingkup sejak kecil hingga dewasa terus bersama kedua orang tuanya. Menurut Hakam dan Nurdin ${ }^{28}$ model hidup (live model) adalah model yang berasal dari kehidupan nyata, misalnya perilaku orang tua di rumah, perilaku guru, teman sebaya atau perilaku yang dilihat seharai-hari di lingkungan sekitar. Model hidup (live model) terkadang menjadi contoh pertama dalam metode keteladanan, dikarena sifatnya yang nyata dan ada fisiknya sehingga anak lebih condong pada hal tersebut. Teradapat model lain yang dinyatakan Hakam dan Nurdin ${ }^{29}$ seperti model simbolik (syimbolic model) yaitu model-model yang berasal dari sesuatu perumpamaan atau gambaran tingkah laku dalam pikiran seperti tokoh cerita dalam buku, tv, film, radio atau dari berbagai peristiwa lainnya. Selanjutnya ada model deskripsi verbal (verbal description model) model yang dinyatakan dalam suatu uraian kata-kata atau model yang bukan berupa tingkah laku tetapi berwujud instruksi seperti arahan resep masakan, atau tata cara yang menunjukan suatu pembuatan benda dan yang semisalnya.

Keteladan perlu dilakukan secara terus menerus agar memberikan dampak positif terhadap anak. Lickona ${ }^{30}$ bahwasannya dalam membentuk karakter seserang tidak boleh terlepas dari pengetahuan moral (moral knowing), perasaan moral (moral feeling) dan tindakan moral (moral action). Ketiga bentuk penerapan moral ini perlu dilakukan dalam menerapkan pendidikan karakter, pengetahuan moral (moral knowing) memberikan suatu pemahaman akan tindakan yang dikerjakan untuk dapat di katagorikan pada kegiatan yang positif atau pantas dilakukan. Selanjutnya perasaan 


\section{Fastabiq: Jurnal Studi Islam \\ ISSN 2723-0228}

Vol. 2 No. 1 Bulan Juni Tahun 2021

moral (moral feeling) sebagai upaya dalam dampak perasaan yang dilakukan dari berbuat positif pada tahapan ini anak diarahkan untuk memikirkan tindakan yang pantas dilakukan. Tahapan terakhir tindakan moral (moral action) pengimplementasian secara nyata mengenai proses pemahaman, perasaan dan dilanjutkan dengan tindakan yang harus dilakukan dalam melaksanakan kegiatan yang positif.

Peran orang tua sebagai teladan bagi anaknya dalam mengimplementasikan pendidikan karakter pada pembelajaran jarak jauh. Dengan banyaknya aktivitas anak sekarang ini yang dilakukan hanya di rumah, anak akan terus melihat sosok teladan dari kedua orang tuanya. Keteladanan yang dilakukan orang tua menjadikan inspirasi bagi anak untuk diterapkan dalam kehidupannya. Dalam mengimpelementasikan pendidikan karakter selama masa pandemi ini, peran orang tua sebagai sosok teladan amat sangat dibutuhkan oleh anak. Upaya yang dapat dilakukan orang tua agar menjadi teladan bagi anaknya pada masa pendemi dapat dilakukan dengan membimbing dan mengarahkan anak untuk melaksanakan pembelajaran jarak jauh dengan baik atau dapat memberikan kesempatan bagi anak untuk membantu orang tuanya dalam mengerjakan pekerjaan rumah seperti memasak, membersihkan rumah dan kegiatan positif lainnya. Dilakukannya metode keteladanan dalam mengimpelmentasikan pendidikan karakter sangat efektif karena dengan hal tersebut menjadikan sosok orang tua sebagai model hidup (living model) dalam menginternalisasikan nilai-nilai karakter pada kepribadian anak.

\section{Proses Pengimplementasian Pendidikan Karakter}

Upaya dalam mengimplementasikan karakter menurut Lickona ${ }^{31}$ adalah dengan niatan yang kuat untuk meraih keberhasilan dan pembiasaan yang aktif tanpa mudah menyerah. Pentingnya niat yang kuat dalam mengimplementasikan karakter agar terpatri dalam jiwa agar para pelaksana dapat memiliki sikap optimis dan tidak pesimis. Menurut Tafsir $^{32}$ niatan yang dilakukan oleh seseorang merupakan sikap kesungguhan yang maksimal yakni memang terkonsentrasi akan tujuan yang ingin dicapai dan niatan yang kuat harus dibarengi dengan sikap spritual menjadikan segala langkah yang dilakukan manusia memang karena Tuhan. Maka pentingnya orang tua dalam menjalankan perannya dalam mengimplementasikan karakter pada kepribadian anak dengan niatan yang kuat, orang tua harus optimis bahwasannya dengan usaha yang maksimal maka perannya akan berdampak besar pada kerpbadian anak.

Selanjutnya adalah pembiasaan yang aktif dimana dengan langkah tersebut dapat menapak dalam kepribadian anak. Hakam dan $\mathrm{Nurdin}^{33}$ menyatakan bahwasannya kegiatan positif terutama dalam mengimplementasikan dan menginternalisasikan nilai-nilai karakter dengan langkah pembiasaan yang terus dilakukan dengan baik akan berbekas dan tertanam dengan kuat dalam kepribadian anak. Budimansya ${ }^{34}$ dengan kegiatan pembiasaan yang aktif perlu dibarengi dengan pengawasan yang tersusun dengan baik dan suri tauladan yang memerintahkannya kepada anak, pembiasaan yang aktif tetapi tanpa suri tauldan yang baik akan menyia-nyiakan hal tersebut yang pada akhirnya proses implementasi pendidikan karakter tidak tercapai dengan baik. 


\section{Fastabiq: Jurnal Studi Islam \\ ISSN 2723-0228}

Vol. 2 No. 1 Bulan Juni Tahun 2021

Proses pengimplementasian pendidikan karakter dapat dilakukan dengan kegiatan-kegiatan yang ringan namun bernilai positif dan dilakukan dengan aktif setiap hari dapat dipraktikan oleh orang tua terhadap anak-anaknya. Tiga peran orang tua yang telah dibahas sebelumnya selanyaknya orang tua memberikan penguatan niat juga sikap optimis dalam proses pengimplementasia pendidikan karakter yang akan memberikan dampak positif pada kepribadian anak. Menurut Budimansyah ${ }^{35}$ karakter harus terpatri dalam diri sehingga mengokohkan kepribadian menjadi pribadi yang unggul dan memiliki nilai-nilai karakter mulia.

\section{SIMPULAN}

Peran orang tua dalam mengimplementasikan pendidikan karakter pada masa pembelajaran jarak jauh yaitu suatu cakupan peran yang mudah yang harus di dasari dengan niatan yang kuat dan sikap optimisme dalam pelaksanaan pembiasaanya setiap hari. Peran orang tua sebagai pendidik perlu ditanamkan dalam diri pribadi orang tua sehingga menemukan kesadaran penuh akan perannya selama ini. Memberikan motivasi belajar yang serius juga perlu dilakukan oleh orang tua saat ini sebagai upaya menguatkan tekat optimisme anak pada masa pembelajaran jarak jauh. Juga Peran orang tua sebagai teladan penuh yang harus diingat oleh para orang tua, selama dalam lingkungan di rumah anak akan terus memperhatikan tingkah laku orang tuanya, maka diperlukan kesadaran yang penuh bagi orang tua untuk memberikan sikap-sikap yang positif dan bernilai edukasi pada anak.

Saran dari penelitian ini dan juga para peneliti selanjutnya bahwasannya pengembangan teori dalam penelitian ini perlu dilakukan. Penelitian ini merupakan cerminan dan wawasan keilmuan yang perlu disadari sebagai gambaran yang objektif pada masa perkembangan yang ada. Tanpa dipungkiri realitas yang ada setiap zamannya akan berbeda-beda oleh karenya pengembangan yang konsisten dan komprehensif menjadi acuan yang faktual dalam melihat realitas yang ada. 


\section{Fastabiq: Jurnal Studi Islam \\ ISSN 2723-0228}

Vol. 2 No. 1 Bulan Juni Tahun 2021

\section{ENDNOTES}

${ }^{1}$ Handayani, Fitri, and Aan Hasanah. "MODEL PENGELOLAAN PENDIDIKAN KARAKTER DI SEKOLAH PADA MASA PANDEMI." FASTABIQ: JURNAL STUDI ISLAM 1.2 (2020): 145-156.

2 Dasim Budimansyah, Perancangan Pembelajaran Berbasis Karakter (Bandung: Widya Aksara Press, 2012 ), 19.

${ }^{3}$ Muhammad Mushfi et al., "Internalisasi Karakter Religius di Sekolah Menengah Pertama Nurul Jadid" 9, no. 1 (2019): 1-25.

${ }^{4}$ Euis Kurniati, Dina Kusumanita Nur Alfaeni, dan Fitri Andriani, “Analisis Peran Orang Tua dalam Mendampingi Anak di Masa Pandemi Covid-19," Jurnal Obsesi : Jurnal Pendidikan Anak Usia Dini 5, no. 1 (2020): 241.

${ }^{5}$ Agustin Lilawati, "Peran Orang Tua dalam Mendukung Kegiatan Pembelajaran di Rumah pada Masa Pandemi," Jurnal Obsesi : Jurnal Pendidikan Anak Usia Dini 5, no. 1 (2020): 549.

${ }^{6}$ Putu Audina Suksma Cintya Dewi dan Husnul Khotimah, "Pola Asuh Orang Tua Pada Anak Di Masa Pandemi Covid-19," Seminar Nasional Sistem Informasi (2020): 2433-2441.

${ }^{7}$ Achmad Zainuri Arif dan Arin Setiyowati, "Piagam Debest: Integrasi Komitmen Tripusat Pendidikan Untuk Penguatan Pendidikan Karakter di SD Muhammadiyah 24 Surabaya," ELSE (Elementary School Education Journal): Jurnal Pendidikan dan Pembelajaran Sekolah Dasar 1, no. 2b (2018).

${ }^{8}$ Slamet Suyanto, "Pendidikan Karakter Untuk Anak Usia Dini," Jurnal Pendidikan Anak 1, no. 1 (2012).

${ }^{9}$ Thomas Lickona, Pendidikan Karakter (Jakarta: Mizan, 2019).

${ }^{10}$ Marzuki, Pendidikan Karakter Islam, ed. Nur Laily Nusroh (Jakarta: AMZAH, 2015), 19.

${ }^{11}$ Anggy Giri Prawiyogi et al., "Efektifitas Pembelajaran Jarak Jauh Terhadap Pembelajaran Siswa di SDIT Cendekia Purwakarta," Jurnal Pendidikan Dasar 11, no. 01 (2020): 95.

${ }^{12}$ Widya Sari, Andi Muhammad Rifki, dan Mila Karmila, "Pembelajaran Jarak Jauh Pada Masa Darurat Covid 19," Jurnal MAPPESONA, no. 1 (2020): 12.

${ }^{13}$ Abuddin Nata, Pendidikan Islam Di Era Milenial, 2020.

${ }^{14}$ Munif Chatib, Orangtuanya Manusia (Bandung: Mizan Pustaka, 2014).

${ }^{15}$ Muhamad Ramli, "Hakikat Pendidik Dan Peserta Didik," Tarbiyah Islamiyah: Jurnal IImiah Pendidikan Agama Islam 5, no. 1 (2015): 63.

${ }^{16}$ Soetrisno Hadi, "Peranan Pendidik dalam PLH menurut UU No. 4 tahun 1982," Jurnal Hukum \& Pembangunan 16, no. 2 (2017): 170.

${ }^{17}$ Rahminur Diadha, "Keterlibatan orang tua dalam pendidikan anak usia dini di taman kanak-kanak," Edusentris 2, no. 1 (2015): 61-71.

${ }^{18}$ Selfi Lailiyatul Iftitah dan Mardiyana Faridhatul Anawaty, "Peran Orang Tua Dalam Mendampingi Anak Di Rumah Selama Pandemi Covid-19," JCE (Journal of Childhood Education) 4, no. 2 (2020): 71-81.

${ }^{19}$ Amna Emda, “Kedudukan Motivasi Belajar Siswa Dalam Pembelajaran,” Lantanida Journal 5, no. 2 (2018): 175.

20 lbid., 178.

${ }^{21}$ Rachma Dwi Ardiyana, Zarina Akbar, dan Karnadi Karnadi, "Pengaruh Keterlibatan Orang Tua dan Motivasi Intrinsik dengan Kepercayaan Diri Anak Usia Dini," Jurnal Obsesi: Jurnal Pendidikan Anak Usia Dini 3, no. 2 (2019): 494-505.

22 Indrati Endang Mulyaningsih, "Pengaruh Interaksi Sosial Keluarga, Motivasi Belajar, dan Kemandirian Belajar Terhadap Prestasi Belajar," Jurnal Pendidikan dan Kebudayaan 20, no. 4 (2014): 441-451.

23 Ibid., 449.

${ }^{24}$ Adhetya Cahyani, lin Diah Listiana, dan Sari Puteri Deta Larasati, "Motivasi Belajar Siswa SMA pada Pembelajaran Daring di Masa Pandemi Covid-19," IQ (Ilmu Al-qur'an): Jurnal Pendidikan Islam 3, no. 01 (2020): 123-140.

${ }^{25}$ Bagas Kurnianto dan Ravita Deasy Rahmawati, "Hubungan Pola Asuh Orang Tua terhadap Motivasi Belajar Siswa Pada Pembelajaran Daring Masa Pandemi," in Seminar Pendidikan Nasional (SENDIKA), vol. 2, 2020.

${ }^{26}$ Syaepul Manan, "Pembinaan Akhlak Mulia Melalui Keteladanan dan Pembiasaan," Jurnal Pendidikan Agama Islam-Ta'lim 2, no. 1 (2017): 57.

27272727272727 Santoso Tri Raharjo, "Mewujudkan Pembangunan Kesejahteraan Sosial melalui Keteladanan Nasional dan Keluarga," Share: Social Work Journal 5, no. 2 (2015): 114.

${ }^{28}$ Kama Abdul Hakam dan Encep Syarief Nurdin, Metode Internalisasi Nilai-Nilai (Bandung: Maulana Media Grafika, 2016), 114. 


\section{Fastabiq: Jurnal Studi Islam}

ISSN 2723-0228

Vol. 2 No. 1 Bulan Juni Tahun 2021

${ }^{29}$ lbid.

${ }^{30}$ Thomas Lickona, Educating for Character (Jakarta: Bumi Aksara, 2015).

${ }^{31}$ Thomas Lickona, Character Matters (Jakarta: Bumi Aksara, 2019).

${ }^{32}$ Ahmad Tafsir, Ilmu Pendidikan Dalam Perspektif Islam (Bandung: Rosdakarya, 2011).

${ }^{33}$ Hakam dan Nurdin, Metode Internalisasi Nilai-Nilai.

${ }^{34}$ Budimansyah, Perancangan Pembelajaran Berbasis Karakter.

${ }^{35}$ Ibid. 


\section{Fastabiq: Jurnal Studi Islam \\ ISSN 2723-0228}

Vol. 2 No. 1 Bulan Juni Tahun 2021

\section{REFERENSI}

Ardiyana, Rachma Dwi, Zarina Akbar, dan Karnadi Karnadi. 2019. "Pengaruh Keterlibatan Orang Tua dan Motivasi Intrinsik dengan Kepercayaan Diri Anak Usia Dini." Jurnal Obsesi: Jurnal Pendidikan Anak Usia Dini 3, no. 2: 494-505.

Arif, Achmad Zainuri, dan Arin Setiyowati. 2018. "Piagam Debest: Integrasi Komitmen Tripusat Pendidikan Untuk Penguatan Pendidikan Karakter di SD Muhammadiyah 24 Surabaya." ELSE (Elementary School Education Journal): Jurnal Pendidikan dan Pembelajaran Sekolah Dasar 1, no. $2 b$.

Budimansyah, Dasim. 2012. Perancangan Pembelajaran Berbasis Karakter. Bandung: Widya Aksara Press.

Cahyani, Adhetya, lin Diah Listiana, dan Sari Puteri Deta Larasati. 2020 . "Motivasi Belajar Siswa SMA pada Pembelajaran Daring di Masa Pandemi Covid-19." IQ (IImu Al-qur'an): Jurnal Pendidikan Islam 3, no. 01: 123-140.

Chatib, Munif. 2014. Orangtuanya Manusia. Bandung: Mizan Pustaka.

Dewi, Putu Audina Suksma Cintya, dan Husnul Khotimah. 2020. "Pola Asuh Orang Tua Pada Anak Di Masa Pandemi Covid-19." Seminar Nasional Sistem Informasi : 2433-2441.

Diadha, Rahminur. "Keterlibatan orang tua dalam pendidikan anak usia dini di taman kanak-kanak." Edusentris 2, no. 1 (2015): 61-71.

Emda, Amna. 2018. "Kedudukan Motivasi Belajar Siswa Dalam Pembelajaran." Lantanida Journal 5, no. $2: 172-182$.

Hadi, Soetrisno. 2017 . "Peranan Pendidik dalam PLH menurut UU No. 4 tahun 1982." Jurnal Hukum \& Pembangunan 16, no. 2: 169-175.

Handayani, Fitri, and Aan Hasanah. 2020. "MODEL PENGELOLAAN PENDIDIKAN KARAKTER DI SEKOLAH PADA MASA PANDEMI." FASTABIQ: JURNAL STUDI ISLAM 1.2: 145-156.

Hakam, Kama Abdul, dan Encep Syarief Nurdin. 2016. Metode Internalisasi Nilai-Nilai. Bandung: Maulana Media Grafika.

Iftitah, Selfi Lailiyatul, dan Mardiyana Faridhatul Anawaty. 2020. "Peran Orang Tua Dalam Mendampingi Anak Di Rumah Selama Pandemi Covid-19." JCE (Journal of Childhood Education) 4, no. $2: 71-81$.

Kurnianto, Bagas, dan Ravita Deasy Rahmawati. 2020. "Hubungan Pola Asuh Orang Tua terhadap Motivasi Belajar Siswa Pada Pembelajaran Daring Masa Pandemi." In Seminar Pendidikan Nasional (SENDIKA). Vol. 2.

Kurniati, Euis, Dina Kusumanita Nur Alfaeni, dan Fitri Andriani. 2020 . "Analisis Peran Orang Tua dalam Mendampingi Anak di Masa Pandemi Covid-19." Jurnal Obsesi : Jurnal Pendidikan Anak Usia Dini 5, no. 1: 241.

Lickona, Thomas. 2019. Character Matters. Jakarta: Bumi Aksara.

Lickona, Thomas. 2015. Educating for Character. Jakarta: Bumi Aksara.

Lickona, Thomas. 2019. Pendidikan Karakter. Jakarta: Mizan.

Lilawati, Agustin. 2020. "Peran Orang Tua dalam Mendukung Kegiatan Pembelajaran di Rumah pada Masa Pandemi." Jurnal Obsesi : Jurnal Pendidikan Anak Usia Dini 5, no. 1: 549.

Manan, Syaepul. 2017. "Pembinaan Akhlak Mulia Melalui Keteladanan dan Pembiasaan." Jurnal Pendidikan Agama Islam-Ta'lim 2, no. $1:$ 49-65.

Marzuki. 2015. Pendidikan Karakter Islam. Diedit oleh Nur Laily Nusroh. Jakarta: AMZAH.

Mulyaningsih, Indrati Endang. 2014. "Pengaruh Interaksi Sosial Keluarga, Motivasi Belajar, dan Kemandirian Belajar Terhadap Prestasi Belajar." Jurnal Pendidikan dan Kebudayaan 20, no. 4 : 441-451.

Mushfi, Muhammad, El Iq, Nurul Fadilah, dan Universitas Nurul Jadid. 2019. "Internalisasi Karakter Religius di Sekolah Menengah Pertama Nurul Jadid" 9, no. 1:1-25.

Nata, Abuddin. 2020. Pendidikan Islam Di Era Milenial.

Prawiyogi, Anggy Giri, Andri Purwanugraha, Ghulam Fakhry, dan Marwan Firmansyah. 2020. "Efektifitas Pembelajaran Jarak Jauh Terhadap Pembelajaran Siswa di SDIT Cendekia Purwakarta." Jurnal Pendidikan Dasar 11, no. 01 : 94-101.

Raharjo, Santoso Tri. 2015. "Mewujudkan Pembangunan Kesejahteraan Sosial melalui Keteladanan Nasional dan Keluarga." Share: Social Work Journal 5, no. 2.

Ramli, Muhamad. 2015. "Hakikat Pendidik Dan Peserta Didik." Tarbiyah Islamiyah: Jurnal Ilmiah Pendidikan Agama Islam 5, no. 1. 


\section{Fastabiq: Jurnal Studi Islam}

ISSN 2723-0228

Vol. 2 No. 1 Bulan Juni Tahun 2021

Sari, Widya, Andi Muhammad Rifki, dan Mila Karmila. 2020. "Pembelajaran Jarak Jauh Pada Masa Darurat Covid 19." Jurnal MAPPESONA, no. $1: 12$.

Suyanto, Slamet. 2012. "Pendidikan Karakter Untuk Anak Usia Dini." Jurnal Pendidikan Anak 1, no. 1. Tafsir, Ahmad. 2011. IImu Pendidikan Dalam Perspektif Islam. Bandung: Rosdakarya. 